\title{
THE EFFECT OF GREEN BANKING PRODUCT AND GREEN CORPORATE IMAGE ON GREEN CUSTOMERS LOYALITY IN GREEN CUSTOMERS SATISFACTION SYARIAH BANKING MEDIATION
}

Nihayatu Aslamatis Solekah Department of Economic Islamic University of Maulana Malik Ibrahim

Malang, Indonesia

Aslamatiss_1@pbs

\begin{abstract}
Banking has a high potential as a role model for other industries in applying the principles of Sustainable Development. Islamic banking is a bank that has a potential bank business model by implementing green banking, as well as provisions of Bank Indonesia as the Central Bank which has included Green Banking as a concept to be implemented in its business practices. This study developed a research framework to explore the relationship between green banking products and green corporate image green customer satisfaction, and green customer loyalty for Syariah Banking. The analysis technique used to analyze the data analysis Path (Path analysis). The results showed that for green banking products and green corporate image effect directly on green customer satisfaction but green banking product has not to affect directly to customers satisfaction, opposite green the corporate image that affects directly to the green customer's loyalty.
\end{abstract}

Keywords: Green Banking Product, Green Corporate Image, Green Customers Loyalty, Green Customers Satisfaction

| Received January 2019 | Accepted March 2019 | Available online April 2019 |

| DOI: http://dx.doi.org (Editor only)

\section{INTRODUCTION}

Environmental issues for some time have shown an increase in world community awareness about the importance of environmental conservation, this increase is most likely due to the threat of environmental disasters that threaten not only health, but also threaten the survival of humans and their offspring (Wibowo, 2002). Banking needs to adapt interdependently with the environment as a way to win the market competition while also preserving its environment where the role of banks as the driving force of the country's economy in the era of climate the change should optimal contribution (Ardiansari, 2013).

Sharia banks that have declared themselves as Green Banking should be able to implement them not only limited to CSR (Corporate Social Responsibility) programs but must be applied well and mature in its Core Business Competence, so Green Banking does not only become a slogan. Banking has a high potential as a role model for other industries in applying the principles of Sustainable Development. Sharia banking is a bank that has the potential of bank business model by implementing green banking, as 
stipulated by Bank Indonesia as Central Bank that has included Green Banking as the concept that must be implemented in its business practices.

According to Bank Indonesia, the Green Banking is defined as banking in carrying out its business based on the principles of sustainable development (www.mds-qms.co.uk). In addition to having the authority to collect funds from third parties in the form of savings or deposits, banks can add savings products or environmentally friendly financing specifically for environmental groups, students and university students as the environment-based target markets. Not only in the form of green savings products, but banks can improve environmentally friendly banking services in the form of paperless, ebilling, e-banking, a type of service that helps reduce paper use in its service activities (Ardiansari, 2013). It's just that in previous study it was found that sharia banking customers still did not fully understand and aware of green banking practices, especially product green banking, which turned out to not have a significant effect on customer preferences through the marketing mix (Solekah, 2015).

Many studies have examined the relationship between customer satisfaction and customer loyalty (Oliver, 1999; Butcher et al, 2002; Hellier et al, 2003; Gountas and Gountas, 2007; Fornell et al., 2006). Mittal and Walfried (1998) found in his research that product quality has a direct impact on performance, and certainly will affect customer satisfaction, customer loyalty, and intention to repurchase the product or service. Some studies such as Abdullah et al. 2000's research, as well as research by Chang and Tu, (2005) show that the corporate image has a significant impact on customer satisfaction and customer loyalty.

Although, previous research has paid much attention to exploring issues that are relevant to customer satisfaction and customer loyalty, research rarely relates to the green banking issues. So the purpose of this study is to fill the previous research gap. This study proposes rare constructions of green banking products, corporate green images, green customer satisfaction, and green customer loyalty.

This research develops a research framework to explore the relationship between green banking products and corporate green images on green customer loyalty through green customer satisfaction in sharia banking

\section{LITERATURE REVIEW}

\section{Green Banking Product}

To provide customer satisfaction and have implications for customer loyalty, product quality is a good starting point. Johnson and Ettlie (2001) describe that product quality is performance result, which in turn can be labeled as the level of customization and free from defects or how reliable products meet customer requirements. Dimensions of product quality include product packaging, product design, product features, guarantees, etc. (Abdul-Muhmin, 2002). High product quality can get greater acceptance of products from customers and lead to satisfaction of retailers and wholesalers (Schellhase et al., 2000). Chumpitaz and Paparoidamis, (2004); Kotler et al. (2005) provide strong empirical support for product quality that has a positive impact on overall 
customer satisfaction. This shows that maintaining good product quality will make customer satisfaction and subsequently, make customers become loyal customers

\section{Green Corporate Image}

The company's image always has an important role for the organization, whether the benefits are commercial, government or non-commercial. To achieve their goals, companies must remain competitive and stable, good image paves the way for organizations to be easily accepted by stakeholders (Shekari \& Ghatari, 2013). Walters (1978) explains that corporate image is perception developed from the interaction between institutions, personnel, customers, and society and the company's ability to position itself in the customer's mind. While the measure of the institution's ability to meet customer needs, including professional expertise, service, and product quality, and trust is a form of the company's credibility. Keller (1998) has also made credibility a factor that contributes to the overall image of the company.

Furman (2010) and Wan \& Schell (2007) define Green corporate image net value from knowledge, beliefs, ideas or impressions about the organization by customers. Karaodmanoglu \& Melewar (2006) explain that holistic green corporate image is inherent in various product factors which are reflection and form of information and corporate communication. Kang \& Yang (2010) explain that Green corporate image is reputation and corporate identity that consumers perceive in all business.

Berens et al., (2005) showed that green marketing, the concept of green corporate image is relevant to corporate associations that are socially responsible and have an impact on the attributes of such corporate images on the contrary to the outcome. Thus, the main goal of green business is to create an environmentally friendly corporate image construction.

Other research that supports the impact of consumer awareness on green corporate image or reputation as perceived by consumers (Brown \& Dacin, 1997; Fombrun \& Shanley, 1990; Maignan \& Ferrell, 2004; Sen \& Bhattacharya, 2001; Wansink, 1989).

\section{Green Customers Loyalty}

Behara et al, (2002) and Singh and Sirdeshmukh (2000) customer loyalty is customers behavior who maintain relationships with companies through products or services purchased. Oliver (1997) defines that loyalty is a continuous decision to repurchase or become a user of selected product or service in the future. This means that loyalty can be categorized as the decision in the future to repeat the product or service purchase, keep in touch with the company on every occasion as the choice of many other choices.

Backman and Compton (1991) and Martensen et al. (2000) identify that customer loyalty has a positive effect on a company's product or service, accompanied by repurchases and gives advice to others. In addition, customers also act as channels of information by suggesting products or services to friends or family, customer loyalty is also considered a constant source of income for the company, (Reid and Reid, 1993). Customer loyalty can be explained through different perspectives such as behavior, attitude or situational (Chaudhuri and Holbrook, 2001; Uncle, Dowling, et al., 2003). Loyalty Behavior can be 
expressed as acquisition and consumption of behavior carried out by customers after their purchase. Attitude loyalty can usually be expressed through emotional association with the brand along with customer preferences for the brand they buy. In this study, green customer loyalty is the customers desire to maintain their relationship with institutions that have environmental concerns.

\section{Green Customers Satisfaction}

Over the past four decades, research on customer satisfaction has become a major issue both theoretical and practical for marketers (Jamal, 2004). Satisfaction that refers to consumers' assessment of product or service features, or to products or services itself is the level of fulfillment of available and pleasant consumption including the level of overfulfillment of that consumption (Oliver, 1997). Customer satisfaction can be seen from meeting consumer consumption goals as experiences and can be explained by consumers (Oliver, 2006).

With the emergence of environmentalism, customers not only purchase financial services but are more willing to use banking products that produce minimal impact, as well as being a society that is more concerned with the environment. In addition, international environmental regulations have experienced dramatic improvements and have become more stringent in recent years.

This study proposes a rare building - green customer satisfaction - and defined the term as a customer who feels the fulfillment of some of their needs for Islamic banks is good for several purposes. Like the desire to take part in environmental issues or through green products and customers feel that they are taking part in complying with environmental regulations and the sustainability of community expectations

\section{Conceptual Framework and Hypothesis Development}

Based on the study of theory and the results of previous research, the researcher compiled the following frameworks and research hypotheses

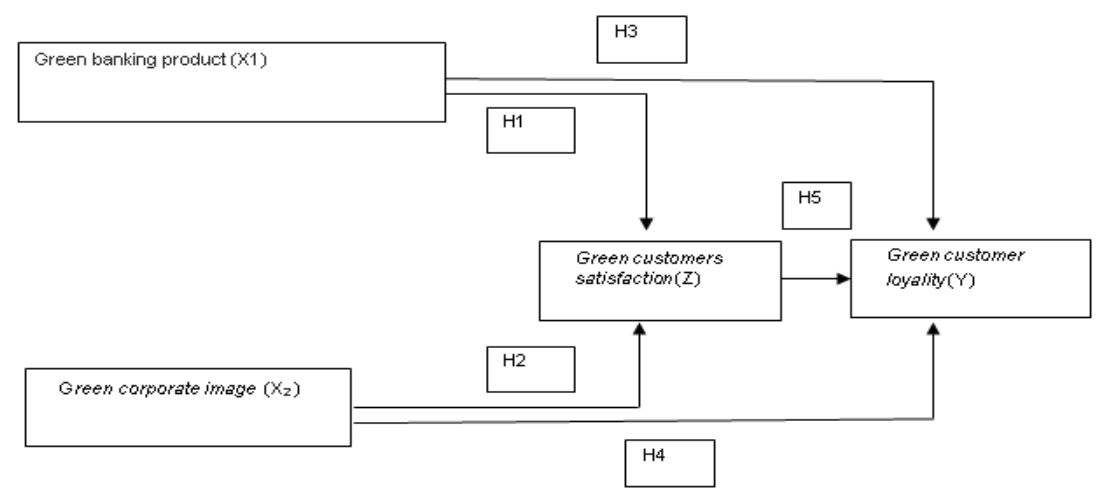

Figure 1. Research Conceptual Model

84 Management and Economics Journal (MEC-J) Vol 3 (1) April 2019 


\section{Hypotheses:}

H.1. Green banking products have a direct effect on green customer satisfaction in of sharia banking

H.2. Corporate green imagery has a direct effect on green customer satisfaction of sharia banking

H.3. Green banking products have a direct effect on green customer loyalty of sharia banking.

H.4. Corporate the green image has a direct effect on green customer loyalty of sharia banking

H.5. Green banking products and corporate green images indirectly affect green customer the loyalty of sharia banking through green customer satisfaction of sharia banking

\section{METHODS}

The study design is a comprehensive plan of research covering the things that will be done by researchers starting from making hypotheses and their implications operationally to the data final analysis which is then concluded and given suggestions. Based on the hypothesis in the study design determined the variables used in the study. There are four variables used in this study, namely green banking products, corporate green images, green customer satisfaction, and green customer loyalty. Next to determine the instrument based on the research variable and then determine the sample. Data collection is done by observation, interviews, and questionnaires. The collected data is processed using descriptive and quantitative analysis tools. The analysis technique used to analyze data is Path analysis. The results of the analysis are then interpreted and the final steps are summarized and given suggestions.

This research was conducted at PT BRI Syariah in 4 cities, namely (1) Soekarno Hatta Malang KC BRI Syariah which is addressed in Jatimulyo Lowokwaru Sub District, Malang City, (2) BRI Syariah Mojoagung which is addressed JL Raya Gambiran no 177 Mojoagung Jombang, (3) BRI Syariah KC Kediri which is addressed at JL Hayam Wuruk Ruko Hayam Wuruk Trade Center Blok A1-2 Kediri and (4) BRI Syariah Cape Pasuruan which is addressed at JL Panglima Sudirman No. 77 Purworejo, Pasuruan City. The choice of 4 locations was to expand the location coverage of previous studies. Besides that, BRI Syariah was chosen because for 2 consecutive years from 2016 and 2017 BRI Syariah won an award at Indonesia Banking Award (IBA) event which was initiated by Tempo Media Group and Indonesia Banking School. The achievements are The Most Efficient Bank \& The Most Reliable Bank (Republika.co.id.). 


\section{RESULTS AND DISCUSSION}

\section{Respondents' Characteristics}

In this study, researchers grouped respondents into several characteristics. The first characteristic is based on the respondent gender which is divided into men and women. Based on the data processed from the questionnaire, most respondents were female. Data on the respondent's characteristics based on the genders are as follows.

The following are presented data on the respondents characteristics based on gender in graphical form.

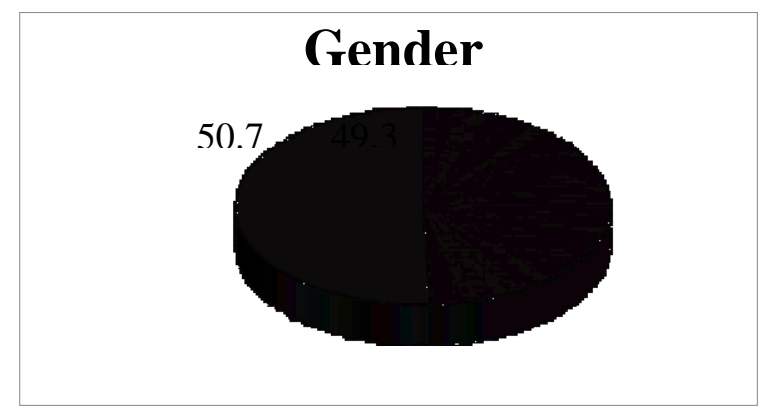

Figure 2. Graph of Respondents Gender

The second characteristic is based on the respondent's age divided into 15-25 years old, 26-35 years old, 36-45 years old, and more than 45 years old. Based on the data processed from the questionnaire, most respondents were 26-35 years old. Data on the respondent's characteristics based on age are as follows.

The following are presented data on respondents characteristics based on age in graphical form.

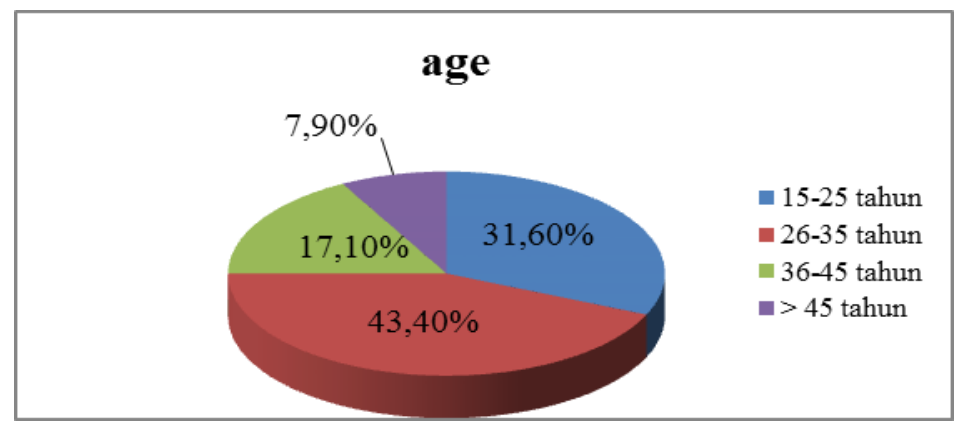

Figure 3. Graph of Respondents Age

The third characteristic is based on the respondent work which is divided into civil servants, private employees, entrepreneurs, students, and others. Based on the data processed from the questionnaire, most respondents were private employees. Data on the respondent's characteristics based on the respondent work are as follows.

The following are presented the respondent's characteristics based on respondents work in graphical form. 


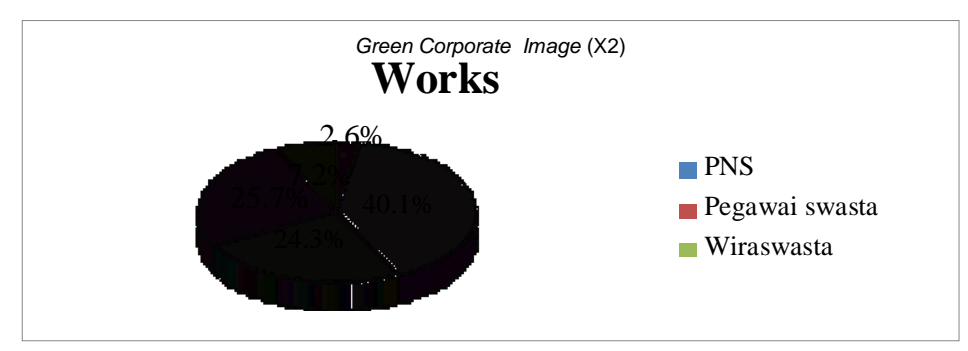

Figure 4. Graph of Respondents Work

The fourth characteristic is based on respondents income divided into less than IDR1,000,000.00; IDR. 1,000,000.00 - IDR 2,000,000.00; IDR 2,000,000.00 - IDR 3,000,000.00; and more than IDR 3,000,000.00. Based on the data processed from the questionnaire, most respondents were in range IDR 2,000,000 to IDR 3,000,000. Data on respondents characteristics based on respondents income are as follows.

The following are presented data on respondents characteristics based on respondents income in graphical form.

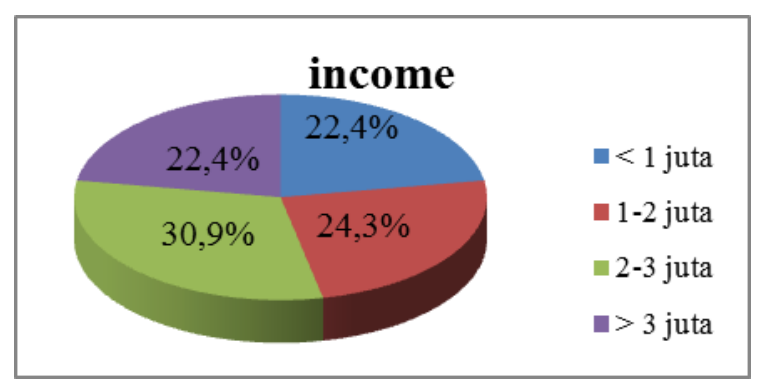

Figure 5. Graph respondents income

The fifth characteristic is based on the being customer period, divided into less than 2 years, 2-5 years, 5-8 years, and more than 8 years. Based on the data processed from the questionnaire, most respondents were 2-5 years. Data on the respondent's characteristics based on the being customer period are as follows.

The following are presented data on the respondent's characteristics based on the being customers the period in graphical form.

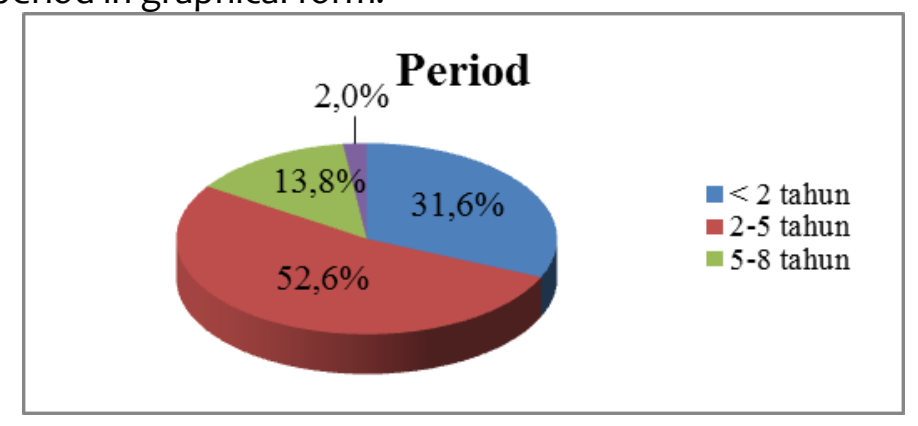

Figure 6. Graph of Being Customer Period 


\section{Green Banking products and corporate green images have a direct effect on green customer satisfaction}

The partial test is used to test the effect of green product quality (X1), corporate green image $\left(\mathrm{X}_{2}\right)$ on green customer satisfaction $(\mathrm{Y})$. The results of $\mathrm{t}$-test statistical analysis can be seen as follows:

Table 1. Direct Impact Test Results of Product Green Banking and Green Corporate Image toward Green Customers satisfaction

\begin{tabular}{|c|c|c|c|c|c|c|c|c|}
\hline \multirow[b]{2}{*}{ Model } & \multicolumn{2}{|c|}{$\begin{array}{l}\text { Unstandardized } \\
\text { Coefficients }\end{array}$} & \multirow{2}{*}{\begin{tabular}{|l}
$\begin{array}{l}\text { Standardized } \\
\text { Coefficients }\end{array}$ \\
Beta
\end{tabular}} & \multirow{2}{*}{ t } & \multirow[b]{2}{*}{ Sig. } & \multicolumn{3}{|c|}{ Correlations } \\
\hline & $B$ & $\begin{array}{l}\text { Std. } \\
\text { Error }\end{array}$ & & & & $\begin{array}{l}\text { Zero- } \\
\text { order }\end{array}$ & Partial & Part \\
\hline (Constant) & 1.450 & 1.033 & & 1.404 & .162 & & & \\
\hline $\begin{array}{l}\text { Green banking } \\
\text { product }\end{array}$ & .092 & .042 & .140 & 2.176 & .031 & .532 & .175 & .114 \\
\hline $\begin{array}{l}\text { Green corporate } \\
\text { image }\end{array}$ & .749 & .071 & .677 & 10.510 & .000 & .758 & .652 & .553 \\
\hline
\end{tabular}

Based on the SPSS testing of individual parameters, the individual testing results of green banking products showed that the value of unstandardized beta coefficients were 0.092 and also the significance of $0.031<0.05$, which means that green banking products directly influence green customers satisfaction.

The results of individual tests of green corporate images showed the value of unstandardized beta coefficients of 0.749 and also the significance of $0,000<0.05$ which means that corporate green images directly influence the green customers satisfaction.

Quality of green banking product which consists of the use of saving account in bank online (online savings accounts), use the paperless transaction reports (Paperless Statements), the payment made by the organization through electronic transfer (Use direct deposit), the payment that allows customers to pay bills via electronic funds transfer (online bill payment), Payment Card Debit and credit (Reward debits and credits cards), transactions, payments, and other transactions over the internet with a website belonging to the bank security systems (net banking) have significant influence on green customer satisfaction.

The results indicated that the quality of green banking products makes green customers feel satisfied because they feel the benefits. This means that what they feel exceeds their expectations. In general, sharia banking customers agree that Sharia banking has implemented online saving accounts, paperless statements, use direct deposits, online bill payments, reward debits, and credit cards and net banking and has an effect on satisfaction with Sharia banking customers. These results are in harmony with Oliver, 2006). Customer satisfaction can be seen from meeting consumer consumption goals as experiences and can be explained by consumers. Chumpitaz and Paparoidamis, (2004) and Kotler et al. (2005) provide strong empirical support for product quality that has a positive impact on overall customer satisfaction.

As for the Green Corporate Image which consists of consumer perceptions about Sharia banking that is consistent and credible, and has a good reputation for the environment,

88 Management and Economics Journal (MEC-J)

Vol 3 (1) April 2019 
and has good performance in environmental management, making customers feel satisfied. Other research that supports the impact of consumer awareness on green corporate image or reputation as perceived by consumers (Brown \& Dacin, 1997; Fombrun \& Shanley, 1990; Maignan \& Ferrell, 2004; Sen \& Bhattacharya, 2001; Wansink, 1989).

\section{Green banking products and corporate green images have direct effect on green customer loyalty}

Partial test or t test is used to test the direct effect of green banking products (X1), corporate green image $\left(\mathrm{X}_{2}\right)$ on green customer loyalty $(\mathrm{Z})$. The t-test statistical analysis results can be seen as follows:

Table 2. Test Results of Direct Influence between Green Banking Products and Green Corporate Image towards Customers Loyalty

\begin{tabular}{|c|c|c|c|c|c|c|c|c|}
\hline \multirow[b]{2}{*}{ Model } & \multicolumn{2}{|c|}{$\begin{array}{l}\text { Unstandardize } \\
\text { d Coefficients }\end{array}$} & \multirow{2}{*}{$\begin{array}{l}\begin{array}{l}\text { Standardize } \\
\text { d } \\
\text { Coefficients }\end{array} \\
\text { Beta }\end{array}$} & \multirow[b]{2}{*}{$\mathrm{t}$} & \multirow[b]{2}{*}{ Sig. } & \multicolumn{3}{|c|}{ Correlations } \\
\hline & $B$ & $\begin{array}{l}\text { Std. } \\
\text { Error }\end{array}$ & & & & $\begin{array}{l}\text { Zero- } \\
\text { order }\end{array}$ & Partial & Part \\
\hline 1 (Constant) & 2.262 & .747 & & 3.030 & .003 & & & \\
\hline $\begin{array}{l}\text { Green banking } \\
\text { product }\end{array}$ & .050 & .031 & .109 & 1.640 & .103 & .502 & .133 & .089 \\
\hline $\begin{array}{l}\text { Green corporate } \\
\text { image }\end{array}$ & .525 & .052 & .680 & 10.198 & .000 & .743 & .641 & .554 \\
\hline
\end{tabular}

a. Dependent Variable: customers loyalty

Based on the SPSS testing of individual parameters, the individual testing results of green banking products showed that the value of unstandardized beta coefficients were 0.092 and also the significance of $0.031<0.05$, which means that green banking products directly influence green customers satisfaction.

The results of individual tests of green corporate images showed the value of unstandardized beta coefficients of 0.749 and also the significance of $0,000<0.05$ which means that corporate green images directly influence the green customer's satisfaction.

Quality of green banking product which consists of the use of saving account in bank online (online savings accounts), use the paperless transaction reports (Paperless Statements), the payment made by the organization through electronic transfer (Use direct deposit), the payment that allows customers to pay bills via electronic funds transfer (online bill payment), Payment Card Debit and credit (Reward debits and credits cards), transactions, payments, and other transactions over the internet with a website belonging to the bank security systems (net banking) have significant influence on green customer satisfaction.

The results indicated that the quality of green banking products makes green customers feel satisfied because they feel the benefits. This means that what they feel exceeds their expectations. In general, sharia banking customers agree that Sharia banking has 
implemented online saving accounts, paperless statements, use direct deposits, online bill payments, reward debits, and credit cards and net banking and has an effect on satisfaction with Sharia banking customers. These results are in harmony with Oliver (2006). Customer satisfaction can be seen from meeting consumer consumption goals as experiences and can be explained by consumers. Chumpitaz and Paparoidamis, (2004) and Kotler et al. (2005) provide strong empirical support for product quality that has a positive impact on overall customer satisfaction.

As for the Green Corporate Image which consists of consumer perceptions about Sharia banking that is consistent and credible, and has a good reputation for the environment, and has good performance in environmental management, making customers feel satisfied. Other research that supports the impact of consumer awareness on green corporate image or reputation as perceived by consumers (Brown \& Dacin, 1997; Fombrun \& Shanley, 1990; Maignan \& Ferrell, 2004; Sen \& Bhattacharya, 2001; Wansink, 1989).

Green banking products and corporate green images have a direct effect on green customer loyalty.

Partial test or t-test is used to test the direct effect of green banking products (X1), corporate green image $\left(\mathrm{X}_{2}\right)$ on green customer loyalty $(\mathrm{Z})$. The t-test statistical analysis results can be seen as follows:

$$
\begin{gathered}
e_{1}=\sqrt{\left(1-R^{2}\right)}=\sqrt{(1-0,583)}=\sqrt{(0,417)} \\
=0,646
\end{gathered}
$$

Based on the $\mathrm{R}^{2}$ test shown in table 20 , the value of $\mathrm{e}_{1}$ obtained.

Empirical causal influence between green banking product variables $\left(\mathrm{X}_{1}\right)$, corporate green image $\left(\mathrm{X}_{2}\right)$ on green customer satisfaction $(\mathrm{Y})$ can be described through structural equation 1 (one), namely:

Green customer satisfaction $=b_{1}$ green banking product $+b_{2}$ green corporate $+e_{1}$

Or

Green customer satisfaction $=0.140$ green banking products +0.677 green corporate image $+0.646 \mathrm{e}_{1}$

Based on the $\mathrm{R}^{2}$ test shown in table 25 , the value of e obtained.

$$
\begin{gathered}
e_{1}=\sqrt{\left(1-R^{2}\right)}=\sqrt{(1-0,623)}=\sqrt{(0,377)} \\
=0,614
\end{gathered}
$$

Empirical causal influence between green banking product variables (X1), corporate green image $\left(X_{2}\right)$ and green customer satisfaction $(Y)$ on green customer loyalty $(Z)$ can be illustrated through structural equation 2 (two), namely:

Green customer loyalty $=b_{1}$ green banking product $+b_{2}$ corporate green image + $b_{3}$ green customer $+e_{2}$ satisfaction

Or 
Green customer loyalty $=0.051$ green banking products +0.399 corporate green image + 0.415 green customer satisfaction $+0.614 \mathrm{e}_{2}$

The interpretation of the results of path analysis can be seen in the following figure 7 :

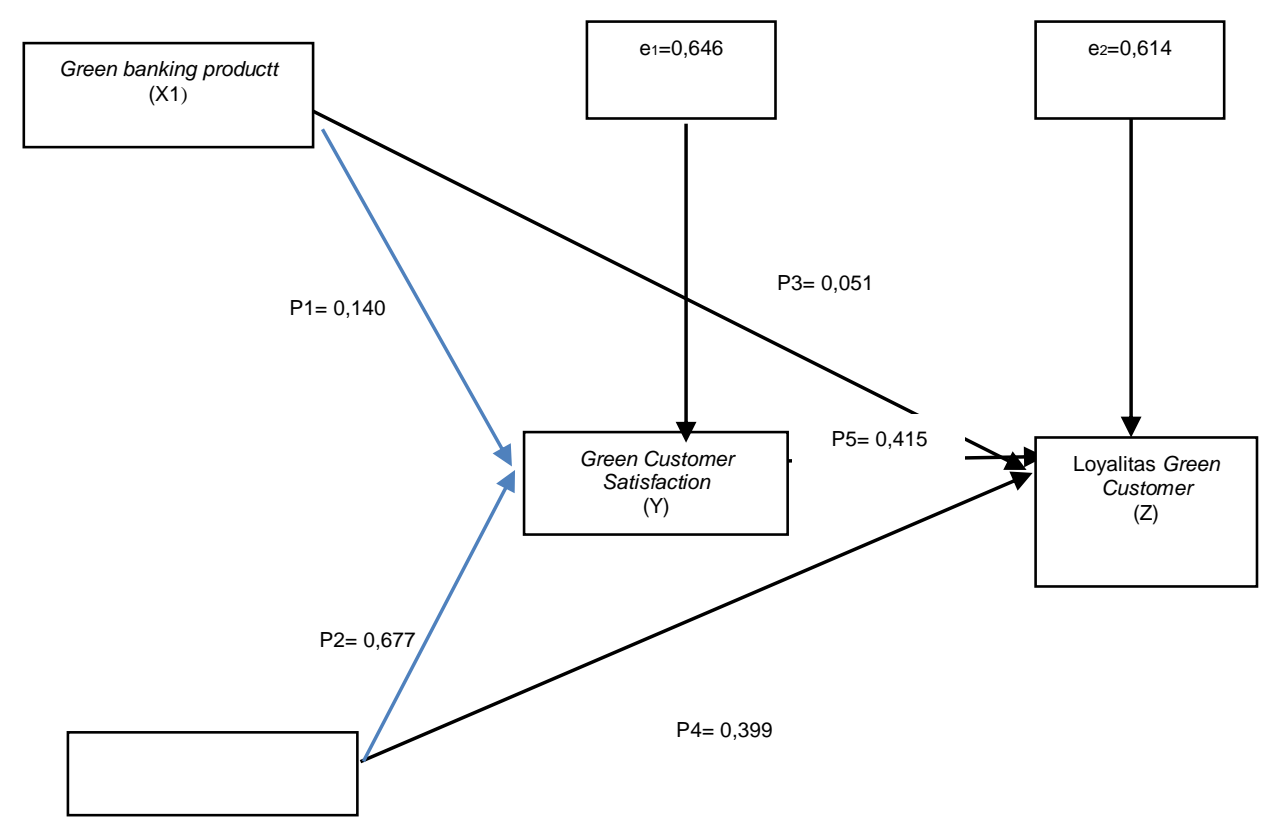

Figure 7. Interpretation of Path Analysis

The results from Figure 7 above are explained in the following Table 3 .

Table 3. Summary of Model Parameter Estimation Results

\begin{tabular}{|c|c|c|c|c|}
\hline Model & $\begin{array}{l}\text { Standardized } \\
\text { beta } \\
\text { coefficients }\end{array}$ & $\mathrm{t}$ & Sig & $R^{2}$ \\
\hline \multicolumn{5}{|c|}{ Structural equation $1\left(X_{1}, X_{2}\right.$ to $\left.Y\right)$} \\
\hline$X_{1}=P_{1} X_{1} Y$ & 0.140 & 2,176 & 0.031 & \multirow{2}{*}{0.583} \\
\hline$X_{2}=P 2 X_{2} Y$ & 0.677 & 10,510 & 0,000 & \\
\hline \multicolumn{5}{|c|}{ Structural equation $2\left(\mathrm{X}_{1}, \mathrm{X}_{2}, \mathrm{Y}\right.$ to $\left.\mathrm{Z}\right)$} \\
\hline$X_{1}=P 7 X_{1} Z$ & 0.051 & 0.822 & 0.412 & \multirow{3}{*}{0.623} \\
\hline$X_{2}=P 8 X_{2} Z$ & 0.399 & 4,932 & 0,000 & \\
\hline $\mathrm{Y}=\mathrm{P} 13 \mathrm{YZ}$ & 0.415 & 5,329 & 0,000 & \\
\hline
\end{tabular}




\section{Direct and Indirect Effects}

In the path model, this study will explain the direct and indirect effects of exogenous variables on endogenous variables.

a) Effect of Product Green Quality on Green Customer Loyalty

Direct effect $\left(X_{1} Z\right)=0.051$

Indirect effects $\left(X_{1} * Y\right)=(0.140) *(0.415)=0.058$

If the indirect effect is greater than the direct effect, it can be concluded that the actual relationship is indirect or not mediating variable. From these results it can be concluded that the quality of the green product does not directly affect green customer loyalty through green customer satisfaction. This is because the indirect effect value is greater than the direct effect $(0.058>0.051)$.

b) The Effect of Corporate Green Image on Green Customer Loyalty

Direct effect $\left(X_{2} Z\right)=0.399$

Indirect influence $\left(X_{2} * Y\right)=(0.677) *(0.415)=0.281$

If the indirect effect is greater than the direct effect, it can be concluded that the actual relationship is indirect or mediating variable. From these results it can be concluded that the green customer image has an indirect effect on green customer loyalty through customers green satisfaction. This is because the indirect effect value is smaller than the direct effect $(0.281<0.399)$.

Table 4. Analysis Results of Direct and Indirect Effects

\begin{tabular}{|l|l|l|l|l|}
\hline No. & Variable & Direct & Indirect & Conclusion \\
\hline 1 & $\begin{array}{l}\text { Green product } \\
\text { quality }\end{array}$ & 0.051 & 0.058 & $\begin{array}{l}\text { Green customer } \\
\text { satisfaction as } \\
\text { mediating variable }\end{array}$ \\
\hline 2 & $\begin{array}{l}\text { Green } \\
\text { corporate } \\
\text { image }\end{array}$ & 0.399 & 0.281 & $\begin{array}{l}\text { Green customer } \\
\text { satisfaction is not } \\
\text { mediating variable }\end{array}$ \\
\hline
\end{tabular}

From the results of the path analysis above it can be concluded that green banking products indirectly have no effect on green customer loyalty through green customer satisfaction. The green banking products quality does not directly affect green customer loyalty through green customer satisfaction. While from the results of path analysis above it can be concluded that the green customer image indirectly affects green customer loyalty through green customer satisfaction. This can be interpreted that if the green the customer satisfaction level is influenced by customer perceptions of the credibility and consistency of Sharia banking and has a good performance on the environment increases, green customer loyalty will also increase. The results of this study are in line with Nai-Jen Chang and Cher-min Fong (2010) who showed a positive relationship between corporate green images of green customer loyalty. This result is different because environmentally friendly financial services will be difficult to be felt

92 Management and Economics Journal (MEC-J)

Vol 3 (1) April 2019 
directly by the green consumer. In contrast to green products that are tangible can be seen, can be seen by the five senses, and clearly the shape of products that are ecogreen compared to financial services

\section{CONCLUSION}

Green banking product, which consists of the use of online savings accounts, use of Paperless Statements, the form of payment made by the organization through electronic transfer (Use direct deposit), the form of payment which allows customers to pay bills through electronic bill payments, Debit and Credit Card Payments, transactions, payments and other transactions via the internet with websites owned by banks equipped with a security system (net banking) provides a significant influence on the green customers satisfaction.

Green Corporate The image which consists of consumer perceptions of Sharia banking that is consistent and credible, and has a good reputation for the environment, and has good performance in environmental management, have a direct influence on customers green satisfaction.

From the path analysis results above it can be concluded that green banking products indirectly have no effect on green customer loyalty through green customer satisfaction. While from the path analysis results above it can be concluded that the green customer image indirectly affects green customer loyalty through green customer satisfaction.

\section{REFERENCES}

Abdullah M, Al-Nasser A, Husain N (2000). Evaluating functional relationship between image, customer satisfaction and customer loyalty using general maximum entropy. Total Qual. Manage., 11(6):826-829

Ardiansari, anindya, (2013). Green Banking : Prioritas Pada Sustainability dalam Praktik Bisnisnya, Proceeding Eco Entrepreneurship Seminar dan Call For Paper Universitas Negeri Semarang

Asnawi, Nur dan Masyhuri. 2011. Metodologi Riset Manajemen Pemasaran. UIN Maliki Press. Malang.

Bhardwaj dan Malhotra (2013) Green Banking Strategies: Sustainability throught Corporate Entrepreneurship...........

Butcher K, Sparks B, O'Callaghan F (2002). Effect of social influence on repurchase intentions. J. Serv. Mark., 16(6): 503-514.

ChumpitazR, Paparoidamis NG (2004). Service quality and marketing performance in business to business markets:exploring the mediating role of client satisfaction. Managing Serv.Qual.,14(2/3) 235-248

Eskildsen JK, Kristensen K, Juhl HJ, Ostergaard P (2004). The drivers of customer satisfaction and loyalty. Total Qual. Manage. Bus.Excell., 15(5/6): 859-868

Chang $\mathrm{CH}$, Tu $\mathrm{CY}$ (2005). Exploring store image, customer satisfaction and customer loyalty relationship: evidence from Taiwanese hypermarket industry. J. Am. Acad. Bus., 7(2): 197-202.

Chang, Nai-Jen.,Fong.,Cher Min (2010). Green Product Quality,Green Corporate Image, Green Customer Satisfaction dan Green Customer loyality.,African of Business management Vol 4(13)PP2836-2844

Fornell C, Mithas S, Morgenson FV, Krishnan MS (2006). Customer satisfaction and stock prices: high return, low risk. J. Mark., 70(1): 3-14. 
Gountas J, Gountas S (2007). Personality orientations, emotional states, customer satisfaction, and intention to repurchase. J. Bus.Res., 60(1): 72-75.

Hellier PH, Geursen GM, Carr RA, Rickard JA (2003). Customer repurchase intention - a general structural equation model. Eur. J.Mark., 37(11-12): 1762-1800.

Kotler P,Amstrong G,Saunders J,Wong V (2005). Principles of marketing, Third European Edition.Essec.London:Prentice Hall

Martenson R (2007). Corporate brand image, satisfaction and store loyalty: a study of the store as a brand, store brands and manufacturer brands. Int. J. Retail. Distribut. Manage., 35(7): 544-555.

Sarita Bahl , 2012, The Role of Green Banking in Sustainable Growth. Asian Journal of Researchin Business economics and Management. Vol 2 pp 176-185

Schellhase R, Hardock P, Ohlwein M (2000). Customer satisfaction in business to business marketing : the case of retail organizations and their suppliers. J.Bus.Ind Mark., 13 (2):106-121

Solekah,Nihayatu (2015). The Efect of Green Marketing to the Preference of Islamic Banking Customers Through Marketing Mix, Proceeding ICONIES : Islamic Economics In Facing Asean Economic Community : 25

Oliver RL (1999). Whence consumer loyalty?. J. Mark., 63(4): 33-44.

Mittal B, Walfried ML (1998). Why do customers switch? The dynamics of satisfaction versus loyalty. J. Serv. Mark., 12(3): 177-194

Wibowo, Budi. 2002.Perkembangan Perilaku Konsumen dan Pendekatan Pemasahan. Usahawan, No.6 Th XXXI Juni, pp: 12-15

Zboja JJ, Voorhees CM (2006). The impact of brand trust and satisfaction on retailer repurchase intentions. J. Serv. Mark., 20(5):381-390

Zins A (2001). Relative attitudes and commitment in customer loyalty models. Int. J. Serv. Ind. Manage., 12(3): 269-294. 